3. Zatilyuk, Y. (2017). The Icon of the Kyiv-Bratsk Bogorodichi from the collection of the National Museum of the History of Ukraine of the XVIII century: origin, attribution, and history. Scientific Herald of the National Museum of History of Ukraine, Issue 2, pp. 79-96 [in Ukrainian].

4. Klimenko, V. A. (2009). Mavory Slobozhanshchyna. Topical issues of history and culture: Materials of the scientific and theoretical conference of teachers, postgraduates and students. Sumy: Sumy State University, pp. 70-76 [in Ukrainian].

5. Kondakov, N. P. (1914). The iconography of the Mother of God: In 2 vol. St. Petersburg: Typography of the Imperial Academy of Sciences [in Russian].

6. Logvin, G. N. (1968). In Ukraine. Ancient art sights. Kyiv: Art [in Ukrainian].

7. Milayeva, L. S. (1994). Miraculous icons of the Virgin in Kyiv XVII century and the image of Lyubecka's Theotokos of the brush of Ivan Shchyrsky. Notes of the Shevchenko Scientific Society, pp. 129-139 [in Ukrainian].

8. Obuhovich, L. (2017). Bogorodchany iconostasis. Volyn Diocesan Information, no. 3 (148), p. 4 [in Ukrainian].

9. Oliynyk, M. (2013). Review of the history of Ukrainian icon painting. Arts centers. Lviv icon painting school of the XVII century. Word, no. 1 (53), pp. 36-37 [in Ukrainian].

10. Pishchanskaya, V. M. (2012). "Protective theme" of the Cossack art. Questions of spiritual culture, no. 219, pp. 154-157 [in Russian].

11. Stepovyk, D. V. Spiritual and artistic dimensions of Ukrainian icons. Kyiv Orthodox Theological Academy. Available at : https://kpba.edu.ua/statti/915-dukhovni-vymiry-ukrainckykhi-ikon.html?start=3 [in Ukrainian].

12. Filaret (Gumilevsky D. G.) (2006). The historical and statistical description of the Kharkiv diocese. Kharkov [in Ukrainian].

13. Melnyk, V. I. (1991). Church of the Holy Spirit in Rohatyn. Kyiv : Art [in Ukrainian].

14. Etingof, O. E. (2000). The image of the Mother of God. Essays on the Byzantine iconography of the XIXIII centuries. Moscow: Progress-Tradition [in Russian].

Стаття надійшла до редакції 27.12.2018 p.

УДК 75.03 (44)“18”+821(4)“18”

Василишина Наталія Анатоліївна, аспірантка кафедри теорії та історії мистецтва

Національної академії образотворчого мистецтва і архітектури

ORCID 0000-0002-00003-9998

eurostudents2010@gmail.com

\title{
ДАНТЕАНА У ФРАНЦУЗЬКОМУ ЖИВОПИСІ ЕПОХИ РОМАНТИЗМУ
}

Мета роботи. Розглянути питання впливу творчості Данте на розвиток французького живопису першої третини XIX століття. Методологія дослідження. Метод формального аналізу дозволяє зрозуміти особливості творчості художників-романтиків, а використання загальнонаукових методів типологізації та класифікації дозволяє розглянути романтизм як феномен західноєвропейської культури. Наукова новизна полягає у виявленні художньо-естетичних особливостей живопису французького романтизму, що виникли під впливом літератури. Простежено зв'язок традицій європейської літератури 3 пошуком нових тем у живописі та особливостями відтворення їх у творчості французьких художників-романтиків. Висновки. У статті були розглянуті особливості розвитку французького романтизму на прикладі творчості французьких художниківромантиків, зокрема Е. Делакруа. У контексті означеної теми досліджена єдність ідей романтизму, які пов'язують образотворче мистецтво і літературу, що дозволяє говорити про унікальність романтичної епохи.

Ключові слова: французький романтизм, література, живопис, композиція, колорит, Данте, Е. Делакруа, Ж.-О.-Д. Енгр, А. Шеффер.

Василишина Наталья Анатольевна, аспирантка кафедры теории и истории искусства Национальной академии изобразительного искусства и архитектурь

Дантеана во французской живописи эпохи романтизма

Цель работы. Рассмотреть вопрос влияния творчества Данте на развитие французской живописи первой трети XIX века. Методология исследования. Метод формального анализа позволяет понять особенности творчества художников-романтиков, а использование общенаучных методов типологизации и классификации позволяет рассмотреть романтизм как феномен западноевропейской культуры. Научная новизна заключается в выявлении художественно-эстетических особенностей живописи французского

(C) Василишина Н. А., 2019 
романтизма, возникшие под влиянием литературы. Прослежена связь традиций европейской литературы с поиском новых тем в живописи и особенностями воспроизведения их в творчестве французских художниковромантиков. Выводы. В статье были рассмотрены особенности развития французского романтизма на примере творчества французских художников-романтиков, в частности Э. Делакруа. В контексте обозначенной темы исследовано единство идей романтизма, которые связывают изобразительное искусство и литературу, что позволяет говорить об уникальности романтической эпохи.

Ключевые слова: французский романтизм, литература, живопись, композиция, колорит, Данте, Э. Делакруа, Ж.-О.-Д. Энгр, А. Шеффер.

Vasylyshyna Nataliia, postgraduate of the Theory and art history chair, National Academy of Fine Art and Architecture

Dantean in French pictorial art of the Romantic era

The goal of the work. To consider the influence of Dante's creative activities on the development of French pictorial art of the first third of nineteenth century. Research methodology. The method of the formal analysis allows us to understand the peculiarities of creative activities of romantic artists, and the usage of general scientific methods of typology and classification allows us to consider romanticism as the phenomenon of Western European culture. The scientific novelty resides in the discovery of the artistic and aesthetic features of French pictorial art of the Romantic era, which arose under the influence of literature. The connection of the traditions of European literature was provided insight into the search for new topics and themes in pictorial art and features of their reproduction in the creative activities of French romantic artists. Conclusions. The article considered the peculiarities of the development of French romanticism by the example of the creative activities of French romantic artists, in particular Eugène Delacroix. In the context of this topic, the unity of the ideas of romanticism, which connects fine art and literature, allows us to speak about the uniqueness of the Romantic era.

Keywords: French romanticism, literature, pictorial art, composition, color, Dante, Eugène Delacroix, JeanAuguste-Dominique Ingres, Ary Scheffer.

Актуальність теми дослідження. Романтизм як напрям в літературі та мистецтві XIX століття відіграв важливу роль в історії світової культури. Важлива роль у розвитку живопису епохи належить французьким художникам-романтикам. Дослідження їх творчості, та плідний взаємозв'язок літератури та живопису, зокрема у творчості Ж.-О.-Д. Енгра, Е. Делакруа, А. Шеффера, є важливим для розуміння французького романтизму як культурного феномена цілої епохи.

Аналіз досліджень і публікацій. Фундаментальним джерелом романтизму стали роботи відомих мистецтвознавців, які досліджували живопис західноєвропейського живопису, зокрема французького романтизму: В. Турчина, В. Березіної, О. Кожиної, О. Дживелегова, О. Гастєва, О. Петрової та ін., а також «Щоденник» [7] самого художника та луврський каталог “Енгр” У. Флекнера [14].

Виклад основного матеріалу. “Божественна комедія” Данте Аліг’єрі (1265-1321) була створена в епоху Середньовіччя, на початку Проторенесансу. Протягом віків, вона залишається одним із найголовніших творів світової літератури. О.К. Дживелегов у своїй роботі “Творці італійського Відродження" зазначає: “Темперамент и пристрасть зробили Данте-поета поетом геніальним. Тілько здатність пристрасно відгукуватися на справи свого часу, тільки здатність пристрасно любити і пристрасно ненавидіти носіїв тієї чи іншої ідеї, живих і мертвих, зробили Данте поетом, зрозумілим усім часам" $[8,272]$.

Поема Данте - шлях людини до свободи. Потрібно подолати важку дорогу: Пекло Чистилище - Рай. Усе це кожному необхідно подолати на шляху до волі, тому в цьому тексті кожний шукає і знаходить своє, особисте, зрозуміле.

В епоху Ренесансу твори Данте, з пробудженням великої цікавості до людської особистості, вперше стали втіленням нових ідей у поетичній формі. А сам автор, дослідивши глибини свого Я “одним цим провів межу між середніми століттями й новою історією” [11, 45].

Класик української літератури Іван Франко у своєму есе “Данте Алігієрі” дає таку оцінку “Данте $\epsilon$ найвищим виразом, поетичним вінцем та увічненням того, що називаємо середніми віками. Уся культура, всі вірування, всі муки й події тих часів знайшли вираз у його поемі” $[13,10]$.

Видатний поет Данте з'являється в італійській літературі в кінці XIII - поч. XIV століття. Поети Флоренції та Болоньї в кінці XIII століття пишуть вірші, які сучасники називали “Дольче стиль ново” (новий солодкий стиль). Поет, натхненний любов’ю, здатний творити. Ця “любов” - поняття набагато складніше, ніж просто любовна лірика, це ціла філософія.

Засновником цього стилю став Гвіло Гвініцеллі (між 1230 і 1240-1276), у Флоренції керманичем стилю став Гвідо Кавальканті (близько 1259-1300). Данте перевершив своїх вчителів, а філософія кохання, відтворена уже у його творах, суттєво вплинула на подальший розвиток всієї 
європейської поезії. Тому тема кохання (поет повинен бути закоханим) - це той крок, який наблизив романтиків XIX століття до Данте.

3 книги Данте "Нове життя" стає відома історія його кохання. Це кохання народилося ще в дитинстві, до доньки його сусіда - Беатріче (Біче). Воно залишилося лише мрією, Беатріче Портінарі пізніше стала дружиною іншого і померла молодою. Кохання Данте тривало все життя, в дусі піднесеного кохання лицарів. Для поета це був середньовічний культ “прекрасної дами” із часів тієї “блакитної троянди” за якою так сумували романтики $[9,150]$.

В епоху середньовіччя “комедією” називали будь-який твір із щасливою розв'язкою. Так як Данте в кінці твору потрапляє в Рай, тому поема і отримала таку назву. Один з перших коментаторів твору Бокаччо додає до назви епітет “Божественна”, відзначаючи найвищу гідність цього твору.

Данте вперше в літературному творі описує свою подорож у потойбічний світ, що для його сучасників здавалось цілком ймовірним і реальним. У складній структурі твору важливе значення має числова символіка, головним числом тут є цифра три - число Трійці. У трьох частинах (кантики), а саме: "Пекло", “Чистилище", "Рай”, по тридцять три пісні в кожній. Твір складається з терцин, це строфа 3 трьох рядків, яка має особливу риму. Символічні й інші особливості цього твору: ім'я Христа римується тільки само 3 собою. Терцини і раніше існували в італійській поезії, вони мали народне походження, одначе, після Данте, така віршована форма почала 3'являтися в подальших наслідуваннях та стилізаціях [9, 154-155].

Для європейської культури автор “Божественної комедії” залишився поетом-вигнанцем. Складне ставлення Данте до Флоренції, неймовірна туга за нею поєднувалась 3 почуттям ганьби та безчестя, так як Флоренція змирилась 3 новою владою. Він знаходить притулок у Вероні, а у Равенні Данте був похований:

Он и после смерти не вернулся / В старую Флоренцию свою. / Этот, уходя, не оглянулся, / Этому я эту песнь пою. /.../ Он из ада ей послал проклятье / И в раю не смог ее забыть... [1, 204205].

В історії образотворчого мистецтва, в епоху Ренесансу, неодноразово був увічнений образ геніального поета. До нього звертались його сучасники, геніальний Рафаель (1483-1520) У «Диспуті», фресці, що стала свідченням нового бачення людини, митця, особистості.

Важливим для подальшого розвитку європейської культури стало повернення цікавості до Данте в кінці XVIII століття, в час формування пре романтизму в Англії.

Протягом XIX століття Дантеана стане відображенням світоглядних художніх моделей, змінивши суттєво культурний клімат всієї Свропи.

Інтерес до Данте у французькому живописі XIX століття розпочинає визнаний класицист епохи Ж.-О.-Д. Енгр (1780-1867). Шукаючи ідеальну красу та намагаючись передати складну гаму почуттів, Енгр, навіть цього не усвідомлюючи, наблизився до табору романтиків. Його захопили нові ідеї - християнство та нові теми з Середньовіччя і Відродження.

У результаті Енгр вибирає один із найромантичніших сюжетів V пісні “Пекла”. У 1814 році він пише найбільш ранній варіант картини "Паоло і Франческа". До цієї теми художник звертався неодноразово. Історія трагічного кохання Франчески да Ріміні та Паоло Малатеста 3 "Божественної комедії" Данте Енгр перетворює в гімн коханню, відстоює гідність людини та ії право на свободу вибору. Натхнення він шукає у флорентійському живописі XV століття та в мистецтві Рафаеля.

У своїй відомій роботі “Жан Огюст Домінік Енгр” В. Н. Березіна пише про те, що майже п’ять років Енгр мріє написати картину на тему “Паоло і Франческа". У дев'ятому зошиті своїх "Нотатків" він ретельно записав усі подробиці цієї історії. Ці зошити під загальною назвою "Нотатки Енгра" він розпочав писати у 1806 році. Всього існує десять зошитів, дев'ять знаходяться в музеї художника в Монтобані, одна - в приватному зібранні $[3,114]$. Як припускає Березіна, думка втілити їхні образи виникла у художника у 1814 році, під час поїздки до Неаполю [3, 114].

Енгр не випадково вибирає саме цей епізод поеми, він співчуває коханцям (хоч вони $є$ грішниками). Художник створює дуже зворушливий, ніжний образ Франчески і сміливий та пристрасний образ Паоло. За свій гріх коханці потрапляють у друге коло Пекла. Автор пропонує нове ставлення до кохання, виступає за свободу вибору. Про цю трагедію, яка сталася у 1289 році, сам Данте дізнався від свого друга - племінника самої Франчески $[3,113]$. Франческа, яку ошукали та видали заміж за кульгавого потвору Джанчотто, покохала його брата - красеня Паоло. За це вони обоє були вбиті чоловіком. Цього ревнивого чоловіка Данте зустріне в дев'ятому колі. Таке кохання гріх, тому коханців чекало покарання. Вони у Пеклі змушені кружляти у вічному вихорі, навіть Данте не наважився роз'єднати закоханих, визнаючи право людини на почуття. 
Енгр не вперше пише роботу на тему кохання, однак у Данте він не випадково обирає сюжет, де автор розкриває таємницю психології кохання; йдеться про фатальну дію лицарського роману, який Паоло та Франческа читають разом, про перший поцілунок:

Ми прочитали, як тремтів коханець, / Бо вперше в губи цілував самі, - / I цей от, мій незмінний співвигнанець, / Мені вуста торкнув, з жаги німий, - / Твір і співия за Галеотто мавщи, / Вже того дня більш не читали ми $[6,46]$.

Найвідомішою картиною Енгра на вищезгадану тему є робота 1819 року з колекції Музею витончених мистецтв Анжеру. Проте, існують більш ранні роботи Енгра, датовані 1814 роком, в яких тема кохання Паоло та Франчески отримала більш повне розкриття.

Картина "Паоло і Франческа" з Музею Конде в Шантійї (Іл. 1) деякі дослідники вважають кращою та більш досконалою [3, 114]. Постаті головних героїв автор розміщує в неглибокому просторі кімнати, на тлі світлої гладкої стіни з невеликим круглим вікном. Художник не відволікає глядача від головного сюжетного мотиву зображенням інтер'єру кімнати. Тільки видно горизонталь спинки дерев'яного дивану, якій паралельна плоскість килима, який лежить на підлозі. Ці горизонталі перетинаються вертикаллю - торсом Франчески з прямовисно опущеною рукою. Художник сміливо руйнує врівноважену композицію стрімкою діагоналлю, яка створює певний дисонанс. Цією підкресленою динамічною діагоналлю картини слугує постать Паоло, який у стрімкому пориві пригорнувся до Франчески. Нездоланну пристрасть Паоло художник підкреслює зображенням плаща, який зачепився за край дивану. Пристрасть його передає не стільки вираз обличчя, скільки в надмірно витягнутому профілі та гіперболізовано видовженій шиї, яка порушує всі закони анатомічних норм (не єдиний випадок в живопису Енгра). Положення правої ноги Паоло так і залишається абсолютно незрозумілим.

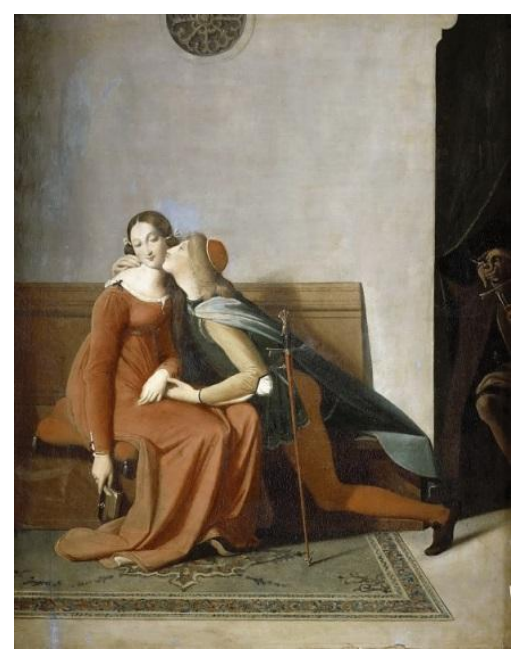

Рис. 1. Ж.-О.-Д. Енгр. Паоло і Франческа. 1819.

Полотно, олія. 35 х 28. Шантійі. Музей Конде

Критик Едмонд Абу в своєму огляді Всесвітньої виставки 1855 року, де була представлена картина Енгра з анжерського музею, з іронією відмітив: “Паоло - не людина, це поцілунок” [3, 118]. У Бірмінгемському університеті зберігається авторський повтор цієї роботи (1814), від попередньої ііі відрізняє лише більш яскравий колорит $[14,219]$. У монографії “Енгр”, виданої музеєм Лувру у 2006 році, представлений цікавий рисунок Енгра, датований 1820 роком (Амстердамський історичний музей) $[14,219]$. Автор повертається до анжерської композиції, однак, ми ії бачимо нібито в дзеркальному відображенні.

Якщо зробити порівняння з іншими варіантами цієї композиції, то очевидно те, що в усіх своїх роботах Енгр залишає незмінним саме поцілунок, який йому вдався найкраще. Окрім варіанту 3 анжерського музею, з яким цікаво зробити порівняння, існують два варіанта, датовані 1819 роком (в приватних зібраннях Парижу і Нью-Йорку), і ще два - 40-х і 50-х років (перший в Музеї Бонна в Байонні, другий - в приватному зібранні в Парижі) [3, 118].

У картині з анжерського музею (1819) по-іншому художник трактує тло і простір (Іл. 2). Тут уже з'являються розграфлені квадратами поверхні стін і стелі. Як встановлено Хансом Нефом, вони були запозичені Енгром із фрески “Диспут святої Катерини”, яку він бачив у церкві Сан-Клименте в Римі $[4,118]$. На стіні з'являється великий килим, із-за якого виступає темна постать Джанчотто, 
який підслуховує, в руці він стискає меч, і трагічна розв'язка тут очевидна. В анжерській картині більше деталей: табернакль, букетик квітів, різьблена маленька лавочка. Можна відмітити більшу ошатність одягу Франчески, i книга, яка випала 3 iï рук “і яка незрозуміло висить в ефектно покладених складках сукні” [3,118 ]. Ці додаткові деталі не роблять ії набагато кращої, ніж перший варіант. Проте, можна погодитися з тим, що вираз обличчя Франчески, та їі сумні очі (передчуття трагедіï) в анжерському варіанті більш виправдані, ніж явно кокетливий погляд в роботі 3 музею в Шантійї.

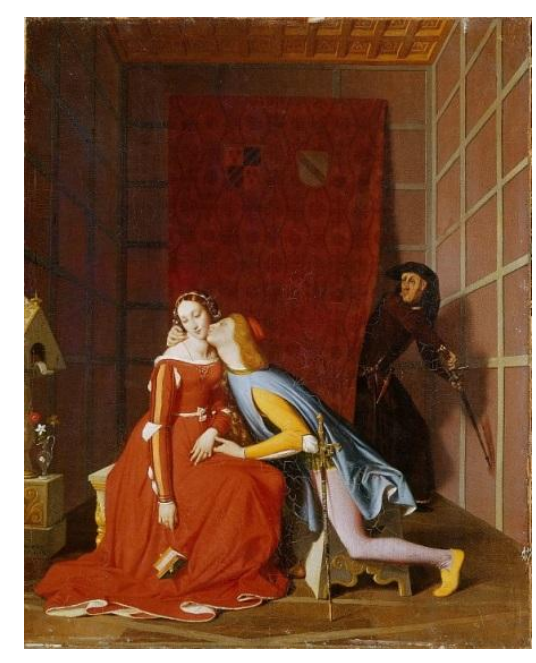

Рис. 2. Ж.-О.-Д. Енгр. Паоло і Франческа. 1819. Полотно, олія. 48 х 39. Анжер. Музей витончених мистецтв

Енгр - один 3 найталановитіших учнів Давида, чия творчість за своїм характером дуже складна і оригінальна. Суто особиста інтерпретація художником будь-якого явища дуже зближує його з романтизмом, хоч він сам романтиком ніколи себе не вважав; між ним і Делакруа ніколи не було непереборної прірви, так як протягом творчого життя Енгра простежуються романтичні тенденції.

Довгоочікуваний Салон 1822 року. Після неодноразових відстрочок він нарешті відкрився. Картина, яка принесла славу молодому художнику Ежену Делакруа (1798-1863) і яка стала ледь не головною подією виставки Салону 1822 року - "Човен Данте". Сюжет іiі був навіяний образами “Божественної комедії” видатного італійського поета Данте Аліг’єрі (Іл. 3).

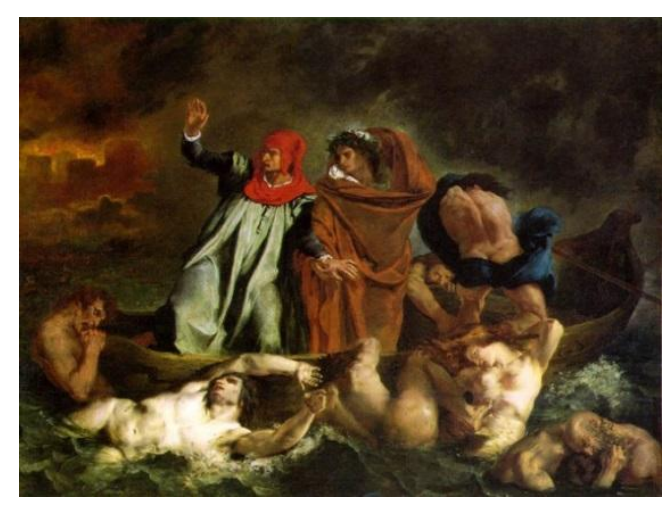

Рис. 3. Е. Делакруа. Човен Данте. 1822. Полотно, олія. 188 х 241. Париж. Лувр

У “Лівре” (каталозі виставки Салону) під № 309, як належало тоді, було надана розгорнута назва твору, зроблена самим художником: “Данте та Вергілій, супроводжувані <...> Флегієм, перетинають озеро, яке оточує стіни пекельного міста Діта. Грішники чіпляються за барку, намагаючись залізти туди. Данте впізнав серед них флорентійців” [2, 51]. Художник представив велике полотно розміром 189x246 см, воно мало дату та підпис художника. 
Відомо, що в каталозі творів Делакруа, 1884 року, була згадана картина Делакруа (нині втрачена), де був зображений човен з людьми на тлі величезної хвилі. Вірогідна дата їі створення 1821 рік, і в каталозі вона була позначена під назвою “Потерпілі корабельну аварію” [2, 51].

Враховуючи дату іï створення, варто припустити, що вона стала безпосереднім відгуком на роботу Т. Жеріко “Пліт “Медузи” (1818-1819).

Зрозуміло, з якою увагою Делакруа ставиться до живопису свого друга, до образів, створених ним. На відміну від Жеріко, Делакруа своїх героїв шукає не серед сучасників, його більше приваблюють літературні персонажі. У “Щоденнику” 11 квітня 1824 року він записує: "Цілу годину я сумніваюся у виборі між Мазепою, Дон-Жуаном, Тассо і багатьма іншими <..> Що ж слід було б зробити, щоб знайти сюжет? Відкрити книгу, яка здатна надихнути, і довіритися своєму настрою! Є книги, які завжди надають свою дію. Їх-то, як і гравюри, і треба мати під рукою. Це - Данте, Ламартін, Байрон, Мікеланджело "[7, 42].

Як справжній академіст, він звик спиратися на античний міф або біблійний сюжет. Література в епоху романтизму надає йому набагато більше можливостей, проте, Делакруа продовжує залишатись під великим враженням від шедевру Жеріко, і тому він у 1821 році пише картину "Після корабельної аварії, а згодом знаходить більш вражаючий сюжет у Данте.

Ежен Делакруа розпочав роботу над картиною "Човен Данте" на початку 1822 року. У листі до своєї сестри мадам де Вернінак від 9 лютого 1822 року Делакруа пише: “Я дуже зайнятий. Я хотів би закінчити те, що я зараз розпочинаю, тобто зробити за два місяці картину, достатньо значну, щоб принести мені популярність” $[2,51]$.

В Луврі знаходяться так звані “Зошити юнацьких начерків”, які свідчать про те, що Делакруа довго вагався, який саме сюжет вибрати з Данте. Збереглися його рисунки до Пісні першої, Пісні третьої, нарешті художник вирішив зупинитись на Пісні сьомій та Пісні восьмій $[2,51]$.

Жадоба Делакруа до творчості в період роботи над картиною перетворюється у справжню одержимість мистецтвом. На початку 1822 року Ежен Делакруа знімає на декілька місяців крихітне ательє в пасажі Соліньє, втискує туди велике полотно і починає працювати 3 властивим йому в той період гарячковим темпом. Завзятість майстра просто вражаюча, він сам вважав, що все написане за одним присідом буде набагато краще, ніж те, до чого потрібно повертатись знову. І в цій одержимості він також наслідував Жеріко.

Коли до майстерні завітав Орас Верне, вельми відомий вже живописець, він дав молодому Делакруа дуже корисну пораду: “Картину треба встигнути написати, доки вона в твоїй владі” [5, 91].

Делакруа наполегливо працює, незважаючи на погіршення здоров’я: “Думка про картину, яку я повинен написати, переслідує мене, як привид. Мені хотілось би зараз опинитись у майстерні... Я не раз намагався писати під час своєї лихоманки...." $[10,128]$.

Через багато років, у 1853 році, художник згадував про свою роботу над цією картиною: "Найкраща голова на моєму полотні Данте була написана з неймовірною швидкістю і зацікавленістю саме тоді, коли П'єрре читав мені одну з пісень Пекла, яку я знав раніше, але він своєю інтонацією надав їй енергію, яка наелектризувала мене. Це голова людини, яка знаходиться навпроти глядача у глибині, він намагається влізти в човен, зачепившись рукою за борт" [ 7, 422-423 ].

Неймовірний підйом та напруга художника втілились в справжньому шедеврі романтичної епохи: “Я працював по дванадцять-тринадцять годин за день... Я закінчую нелюдську роботу, яка поглинала протягом двох з половиною місяців кожну мою хвилину...” $[10,128]$.

Картина виставлена в Салоні 1822 року. Журі дозволило авторові іï представити. Вона вражає! Неймовірний колорит! Синьо-зелені, густі, навіть лиховісні барви викликають у глядача відчуття жаху ще раніше, ніж він підійде ближче, та роздивиться картину:

Збігаючи в ненависну пітьму, / Спливала річка, наче під ворота, / Під те багно, що Стікс ім'я йому. / Я, придивившись, щзо то за сквернота, / Побачив тіней голих гурт тісний, / Занурений в драговину болота. / Не лиш руками билися вони, / А й головою, і грудьми, й ногами, / А хто й зубами гризся, навісний... [6, 54].

Величезна картина Делакруа просякнута суцільним пекельним мороком, промінь світла вихоплює з темряви постаті Данте та Вергілія, які ледве утримуються в хисткому човні. Оскаженілі обличчя мерців, оголені їхні тіла, вони намагаються вчепитись руками за човен, руйнуючи рівновагу, та вносячи в композицію несподівану та неочікувану динаміку пекельного виру, який може поглинути головних героїв.

Академічні правила майстерні Герена, яку закінчив автор, відчуваються у Делакруа в намаганні побудувати композицію відповідно до класичного трикутника. Проте, динамічні пружні лінії, що перетинаються, енергійні ракурси та жести, є тією несподіваною силою, яка здатна затягти 
героїв у Пекло назавжди. Болісне занепокоєння викликає хвилястий ритм ліній. Цей нестерпний, похмурий пекельний подих смерті перебуває у постійному русі. Темні тони - похмурі, сіро-сині та сіро-зелені, коричневі. Колорит Тиціана та Рубенса, добре опрацьований художником, надихає Делакруа на сміливі рішення. Ще Фромантен помітив особливість колориту художника: “...дивовижно живий, одухотворений і поліфонічний колорит картин Делакруа містить у собі і драму, і радість” $[2,179]$.

Данте в картині Делакруа висловлює протест пекельним жахіттям, він піднімає руку, намагаючись відсторонитись від нових видінь. Відповідно до тексту Данте, поета вразило не Стігійське болото з грішниками, перед ним вже відкривається панорама наступного кола Пекла. В цьому пекельному мороці його яскраво-червоний капюшон утверджує право на життя плямою живого вогню. Йому відлунюють зловісні червоні тони заграви згарищ. Сіро-голубий плащ поета, спадаючи складками, контрастує з темним коричневим одягом Вергілія. Закутаний в римську тогу, 3 лавровим вінком на голові, він не приймає участь в цій боротьбі (бо не належить до світу живих).

Жахливий рій видінь, які приніс з собою попільний вітер пекельного міста Діта розступається, дозволяючи човну плити далі, але примарний інфернальний відтінок всієї сцени не залишає глядача байдужим.

Композиція цієї картини народилась у Делакруа доволі швидко, так як існує один-єдиний ескіз олією (25x35 см), який зберігається в колекції мадам Давид-Вейль у Парижі. Ця композиція майже без змін і була перенесена на велике полотно $[2,51]$.

У роботі над картиною майстер активно користується творами своїх найулюбленіших художників - Мікеланджело, Рубенса, Жеріко. Делакруа звертається за натхненням до античності робить замальовки зі спини з Бельведерського торсу (ймовірно з гіпсу, який знаходився в Школі витончених мистецтв у Парижі). Замальовує профільні зображення облич з римських монет для голів Данте та Вергілія [2, 52].

Зі слів П'єра Андріє, улюбленого учня Делакруа, нам відомо, що Делакруа писав усіх персонажів картини з одного натурника на ім'я Сюісс, окрім Флегія, для якого художник використав античний торс [2,54].

В Пісні восьмій (п'яте коло пекла) Данте описує свою зустріч з “флорентійським духом” Ардженті, який належав до “чорних гвельфів” - ворога поета, так як він сам належав до партії “білих гвельфів”. Після розколу єдиної партії гвельфів (яка виступала проти монархії) Данте у 1301 році змушений був покинути Флоренцію, тоді він виголосив: “Я - сам собі партія". Одначе, Делакруа вирішив надати роботі загальнолюдського звучання, щоб ії сюжет хвилював глядача і через багато років, тому він свідомо не став зображувати “флорентійців”, як це заявлено в каталозі, справедливо вважаючи ці рядки поеми проявом суто особистого дантівського ставлення до політичного суперника.

Флегія художник зображує зі спини. Флегій (Флегіас) - герой грецької міфології, який ненавидів Аполлона (і поезію), і який спалив знаменитий храм Аполлона в Дельфах, щоб йому помститись. За це його спіткала кара, він після смерті засуджений на вічну кару, він повинен сидіти під скелею, яка готова постійно обвалитися. Вергілій у своїй поемі “Енеїда” в книзі шостій розповідає про подорож Енея, який у супроводі Кумської Сівілли спускається в підземне царство, де він бачить тіні померлих. Серед них він зустрічає і Флегія:

... и самый из всех злаполучнейший Флегий / Увещевает и гласом клянется великим меж теней: / “Не презирать богов на примере / учитесь и правде!” [ 4, 267-269].

На думку Делакруа, така поза Флегія продиктована тим, щоб його розлючене обличчя не відволікало глядача від сприйняття образу Данте.

В своїй статті “Барка Данте” В. Березіна, спираючись на дослідження англійського дослідника Лі Джонсона, які були опубліковані в журналі “Бьорлінгтон Магазен” за 1958 рік, наводить основні аналогії творчого пошуку Делакруа [2, 52].

Крайня ліва постать грішника, який зубами вчепився в борт човна, нагадує рисунок невідомого майстра початку XIX століття “Уголіно у в'язниці” (Париж, Школо витончених мистецтв). Цю трагічну постать ми зустрічаємо в 32 та 33 піснях пекла у Данте. Щоб краще відтворити напруження лицьових м'язів, Делакруа примусив натурника вкусити велике тверде яблуко або окраєць черствого хліба $[2,52]$.

Щоб реалістично відтворити крайню постать праворуч (із закиненими за голову руками), автор створює цілу низку рисунків, де той же натурник чіпляється за мотузку [2, 52].

Цікаво розглянути цю оголену постать, як і постать поруч. Тут дуже ймовірний вплив однієї 3 ранніх робіт Рубенса “Геро і Леандр”. Делакруа дуже цікавився ранніми роботами художника. Голова 
цього грішника ( в іншому розвороті) також дуже нагадує одну з голів Жеріко в картині “Пліт “Медузи”. Дуже перероблений за рисунками з натури, одначе, ще учень Делакруа помітив схожість жіночої постаті в правій частині картини з “Ніччю” Мікеланджело [2, 54]. Не можна не погодитись, що постать Данте, його руки, складки одягу - все це є дуже близьким з роботами Мікеланджело. Очевидні паралелі зі статуєю "Рахіль", яка символізує у Мікеланджело “життя споглядальне”, адже такою зобразив іiі Данте в “Божественній комедіi”":

“Коли питаєшся, хто я така / Й чого квітки збираю, знай, - я Лія, / I гарні руки ичі плетуть вінка, / Бо дзеркало оздобить - в мене мрія, / Не чинить так сестра моя Рахіль: / Вдивлятися в нього - изе для неї дія. / Для неї зір -мета дбання й зусиль, / А я иікавлюсь рук свойх діянням, / Їй споглядать, для мене ж діять - изіль” [6, 305 ].

Постать Вергілія єдина в картині, для якої Делакруа не робив ніяких замальовок 3 живої натури. Велику увагу демонструє художник до майбутнього твору, його обличчя Делакруа знайшов на античній монеті.

Один $з$ найулюбленіших образів романтизму - море. Особливо бурхливе море - зі штормами, величезними хвилями, блискавками, приваблювало романтичну уяву. У Делакруа розлючена стихія зі свинцевими хвилями є персоніфікацією стихії життя, а поет намагається подолати всі перешкоди на життєвому шляху. Він є сильною особистістю, бунтар, який постав проти ворожого суспільства.

Картина Делакруа викликала гучні баталії, подібні до тих, які виникнуть пізніше у зв’язку 3 драмою В. Гюго “Ернані'. В “Журналь де Деба” Делаклюз вимовляється доволі різко: “Це не картина, а різнобарвна мазанина...” [5, 49]. Його навіть звинувачують у плагіаті з творів старих майстрів. Сам Герен, який на запрошення художника відвідав його ательє і побачив уже завершену роботу, не радив Делакруа картину виставляти в Салоні. Сдиний, хто зрозумів та підтримав, був Теодор Жеріко, який сказав, що міг би сам, із задоволенням, підписати цю картину.

В газеті “Конститусьонель” через декілька днів виходить стаття Адольфа Тьєра, яка нарешті зробила молодого Делакруа щасливим: "Ніяка картина, по-моєму, не розкриває майбутнього видатного художника так, як картина Делакруа, яка зображує Данте і Вергілія в Пеклі... Саме тут помітний могутній порив таланту, який відновляє наші надії, вже майже зниклі...” [5, 49].

Роботу Делакруа вирізняє певна суворість смаку, а на думку багатьох сучасників, навіть нестача шляхетності. Колір досить сильний, навіть різкий, а пензель широкий та міцний.

Далі Тьєр пише: “Делакруа кидає свої постаті, вигинає їх самовільно зі сміливістю Мікеланджело і численністю Рубенса. Ця картина нагадує роботи видатних майстрів, в ній бачиться дика природна сила, яка рухається за своєю сваволею. Я думаю, що не помилюсь, якщо скажу, що Делакруа геніальний. Нехай він іде вперед впевнено, нехай змагається за величезні результати, які необхідні такого роду таланту" [5, 49-50].

Антуан Гро, високо цінуючи картину Делакруа, замовив за свій кошт для неї золочену раму. Твір “Човен Данте” буде гідно оцінений вже через декілька десятиліть, юнацький твір Делакруа стане необхідною сходинкою для вдосконалення таланту майбутніх художників, а для сучасників Делакруа “Човен Данте” став справжнім “маніфестом” нового мистецтва.

У цій роботі романтизм Делакруа досягає неймовірної пластичної цілісності. Могутній сплав вражаючих емоцій у поєднанні 3 новою живописною тенденцією, яка вперше демонструє органічний зв'язок між почуттями художника і вмінням знайти відповідні пластичні засоби для їх втілення.

3 новаторством романтизму був співзвучний динамізм самої поеми Данте, адже світ навколо рухливий, мінливий, а не усталений. Живопис романтиків пропонує сюжети, де є місце конфліктам, контрастам, він починає утверджувати нову естетику. Поезія Данте дає поштовх до романтичного бунту, а сама особистість поета якнайкраще ілюструє приклад героя-бунтівника доби романтизму. Для всього XIX століття "Човен Данте" Делакруа став твором, який вперше у французькому живописі XIX століття втілив сам бунтівний дух епохи. Данте.

У французькому живопису ХІХ століття працювали і інші художники, інтерпретатори твору

Натхненний Данте, відомий французький художник Арі Шеффер (1795-1858) представляє в Салоні 1822 року свою картину “Привиди Франчески да Ріміні і Паоло Малатеста з'являються Данте і Вергілію”. Делакруа виставляє свою роботу - “Човен Данте”. Тракування дантівського твору абсолютно різне при аналогічному виборі сюжету та зображуваних образах (Іл. 4).

Порівняючи цю роботу з картиною Е. Делакруа “Човен Данте” О. Кожина в своїй роботі "Романтична битва” висловлюється дуже категорично: “Але обидва полотна настільки непорівнянні, що навіть хвилинне зближення їх здається непрощенним. Те, що було трагедією на полотні Делакруа, 
перетворилося у Шеффера в сентиментальну мелодраму <..> Данте і Вергілій - тривіальні формули співчуття, Паоло і Франческа - штампи нещасних коханців" [10,95].

Не будемо настільки категоричні в оцінці цього твору. Безумовно, все новітне у французькому живописі першої третини XIX століття пов' язане 3 романтизмом, проте, предромантичні тенденції в цей період часто співіснують 3 класицистичними.

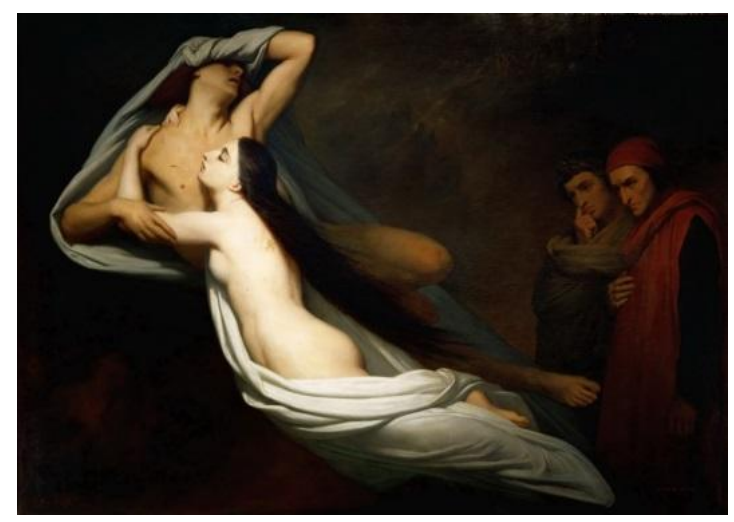

\section{Рис. 4. А. Шеффер. Привиди Франчески да Ріміні і Паоло Малатеста з'являються Данте і Вергілію. 1822. Полотно, олія. 171 x 239. Париж. Лувр.}

У тридцятих роках XIX століття Шеффер він був одним з наймодніших художників Парижу. Він був відомий своїми роботами на релігійні сюжети, але найбільшу славу йому принесли сентиментальні жанрові картини, які користувались великим попитом у публіки.

Делакруа згадує Шеффера у своєму щоденнику, вони разом вчились у майстерні Герена. Не позбавлений таланту, художник викликав великі сподівання, а його роботи дуже високо цінувались.

Арі Шеффер поставився до цієї роботи дуже серйозно. Він читав "Божественну комедію" в оригіналі. В пекельному напівмороці світла пляма - тіла закоханої пари, який не може роз'єднати навіть Пекло. Досконала краса оголених тіл (майстерня Герена), шкіра Франчески світліша, на темному тлі картини воно, здається, світиться. Обличчя Паоло не видно, ми бачимо його поантичному досконале сильне тіло, рукою він закриває очі, щоб не бачити мороку потойбіччя. Як і в роботі Енгра, центр композиції перетинає стрімка діагональ, ця діагональ - тіло Франчески. Вона пристрасно пригорнулась до коханого, утримуючи його міцно руками. Дуже вдало Шеффер знаходить можливість підкреслити головне - нероздільність цієї закоханої пари, щоб їх поєднати художник додає дуже оригінальну деталь. Довге прозоре покривало, лягаючи красиво складками (як античний одяг) огортає тіла коханців, а складки розташовані таким чином, що ця невагома тканина створює відчуття руху, кружляння:

Кохання, що кохать дає й коханим, / Мене взяло, вогнем наливши вщчерть, / Що став моїм він, як ти бачиш, паном. / Кохання нас вело в злощасну смерть, / Каӥна жде того, хто кров'ю вмився... $[6,45]$

Картина Шеффера, яка відповідала всім вимогам офіційного салонного мистецтва, приваблювала спокоєм та монотонністю коричневої гами, спонукала до мрійливості та рефлексії. В деякій мірі вона вже передбачала літературність та містику, закладала підгрунтя майбутніх ідей символізму.

Висновки. Мистецтво XIX століття займає особливе місце в історії європейської культури. Романтизм як напрям був важливим досягненням епохи, в якій французький романтизм є явищем неповторним та своєрідним.

Враховуючи специфіку образотворчого мистецтва, ми простежили ступінь впливу літератури на розвиток французького живопису, та виявили джерел художньої природи романтизму. Французькі художники-романтики в пошуках нових сюжетів активно звертаються до літературних творів. Ежен Делакруа першим побачив у Данте сильну та вільну особистість, відчув гостроту емоцій та напруження, зловісна і трагічна патетику твору, яка ідеально відповідала романтичним вподобанням художника. Твір Данте “Божественна комедія" знайшов геніальне втілення у французькому живописі епохи, особливо у різноспрямованих у творчості академічних майстрів Е. Делакруа, Ж.-О.-Д. Енгра та А. Шеффера. 


\section{Лimepamypa}

1. Ахматова А. А. Лирика. Москва: Художественная литература, 1990. 415 с., ил.

2. Березина В. Н. Барка Данте. Художник. Москва, 1970. № 8. С. 51-55.

3. Березина В. Н. Жан Огюст Доминик Энгр. Москва: зобразительное искусство, 1992. 246 с., ил.

4. Вергилий. Буколики; Георгики; Энеида. Харьков: Фолио; Москва: ООО “Издательство АСТ”, 2000. 510 с. (Б-ка антич. лит.).

5. Гастев А. Делакруа. Москва: Молодая гвардия, 1966. 223 с.

6. Данте Аліг’єрі. Божественна комедія: Поема. Харків: Фоліо, 2001. 607 с. (Б-ка світової літ.).

7. Делакруа Э. Дневник в 2-х томах; пер. с фр. Т. М. Пахомовой; ред. и предисл. М. В. Алпатова. Москва: Изд-во Акад. художеств СССР, 1961. Т. 1. 451 с. : ил.

8. Дживелегов А. К. Творцы итальянского Возрождения: В 2 кн. Москва: ТЕРРА - Книжный клуб; Республика, 1998. 352 с.

9. Кирилюк 3. В. Зарубіжна література. Античність, Середньовіччя, Відродження, Бароко. Класицизм. Тернопіль: Астон, 2002. 259 с.

10. Кожина Е. Ф. Романтическая битва. Ленинград: Искусство, 1969. 271 с.

11. Петрова О. “Комедія” Данте Аліг’єрі. Мистецький коментар XIV-XX століть. Київ: Факт, 2009. 424 с.; іл.

12. Турчин В. С. Теодор Жерико; Монография. Москва: Изобразительное искусство, 1982. 208 с., ил.

13. Франко I. Данте Алігієрі. Характеристика середніх віків. Життя поета і вибір із його поезії. Зібрання творів у 50 томах. Т. 12. К., Наук. думка, 1978. 728 с.

14. Fleckner U., Foucart B., Guegan S., et al. Ingres. Paris, Musee du Louvre editions, 2006. 406 p.

\section{References}

1. Akhmatova A. A. (1990). Lyrics. Moscow: Khudozhestvennaya literature [in Russian].

2. Berezina V. N. (1970). The Barque of Dante. Moscow: Khudozhnik [in Russian].

3. Berezina V.N. (1992) Jean Auguste Dominic Engr. Moscow: Izobrazitel'noye iskusstvo [in Russian].

4. Vergil. (2000). Bucolica; Georgica; Aeneid. Kharkov: Folio, Moscow: Izdatel'stvo AST [in Russian].

5. Gastev A. (1966). Delacroix. Moscow: Molodaya gvardiya [in Russian].

6. Dante Alighieri. (2001). Divine Comedy. Poem. Kharkiv: Folio [in Ukranian].

7. Delacroix, E. (1961). Diary. (T. M. Pakhomova, trans). (In 2 vols, vol. 1). Moscow: Izdtatel'svo Akademii khudozhestv SSSR. [in Russian].

8. Dzhivelegov A. K. (1998). The Creators of the Italian Renaissance: In 2 books. Moscow: Knizhnyy klub; Respublika [in Russian].

9. Kirilyuk Z. V. (2002) Foreign literature. Antiquity, Middle Ages, Renaissance, Baroque. Classicism. Ternopil: Aston [in Ukranian].

10. Kozhina E. F. (1969). Romantic battle. Leningrad: Iskusstvo [in Russian].

11. Petrova O. (2009) Dante's "Comedy" as viewed by artists of XIV-XX centuries. Kyiv: Fakt [in Ukranian].

12. Turchin V. S. (1982) Theodore Zheriko; Monograph. Moscow: : Izobrazitel'noye iskusstvo [in Russian].

13. Franco I. (1976 - 1981). Dante Alighieri. Characteristics of the Middle Ages. The life of the poet and the choice of his poetry. (In. 50 vols. Vol. 29). Kyiv: Naukova dumka [in Ukranian].

14. Fleckner U., Foucart B., Guegan S., et al. (2006). Ingres. Paris: Musée du Louvre Éditions [in French]. 